\title{
Unique subaortic course of anomalous left circumflex artery associated with double chamber right ventricle
}

\author{
Mumun Sinha, Niraj Nirmal Pandey, Arun Sharma
}

Cardiovascular Radiology and Endovascular Interventions, All India Institute of Medical Sciences, New Delhi, India

\section{Correspondence to} Dr Arun Sharma; drarungautam@gmail.com

Accepted 1 October 2019

\section{DESCRIPTION}

Cardiac computed tomography angiography in a 47-year-old woman, presenting with features of right heart failure, revealed a hypertrophied muscle band in the lower right ventricular outflow tract (RVOT) (figure 1) with resultant dilatation of the right atrium (RA), right ventricular inlet and the RVOT with right ventricular hypertrophy. A small perimembranous ventricular septal defect was also seen.

Incidentally, an anomalous left circumflex (LCx) artery arising from the right coronary artery (RCA) was also present. However, the aberrant vessel was seen to follow an exceedingly rare subaortic course, between the aortic root and dilated RA, to the reach the left atrioventricular groove, instead of the usual retroaortic course (figure 2 ).

Double chamber right ventricle (DCRV), where the right ventricle is separated into a high-pressure proximal and low-pressure distal chamber, is seen in around $0.5 \%-2.0 \%$ of all cases of congenital heart disease, most commonly encountered in infants and children. ${ }^{1}$ An exceptionally rare association of DCRV present in this patient is an anomalous LCx arising from the RCA, more so with a

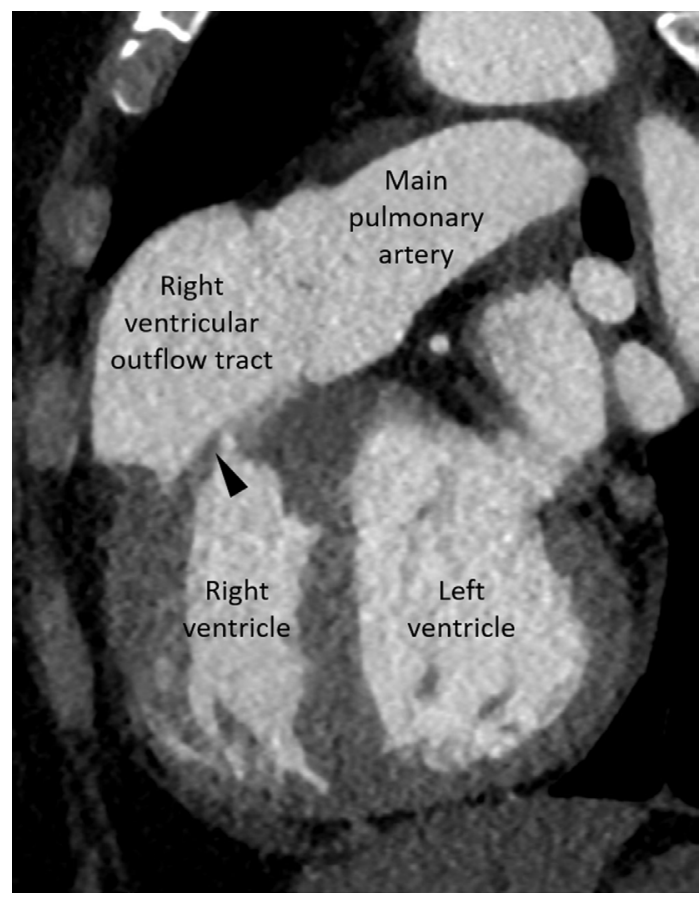

Figure 1 Oblique sagittal image reveals a hypertrophied muscle band (arrowhead) in the right ventricular outflow tract (RVOT) with resultant dilatation of the RVOT with right ventricular hypertrophy.
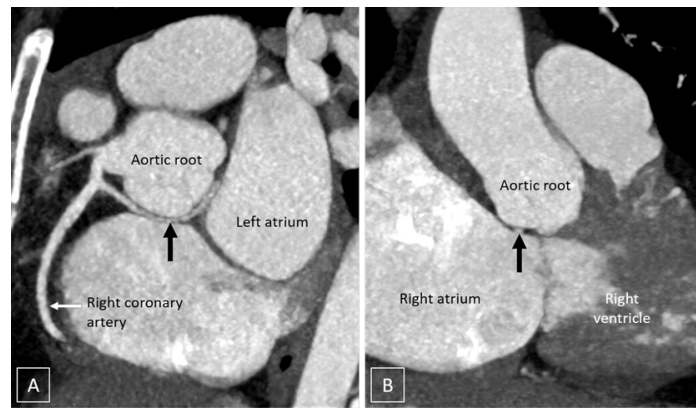

Figure 2 Oblique sagittal (A) and oblique coronal (B) maximum intensity projection images depict the subaortic course of the anomalous left circumflex artery (black arrow), traversing between the aortic root and dilated right atrium.

unique subaortic course. The said association may be clinically important as the anomalous vessel precariously courses between the dilated RA and aortic root where it can get compressed between the two structures. It, therefore, may need either additional correction or close follow-up for resolution of RA dilatation postresection of the hypertrophied muscle band.

\section{Learning points}

- Double chamber right ventricle (DCRV) is rare and seen in around $0.5 \%-2.0 \%$ of all cases of congenital heart disease, most commonly presenting in infancy or childhood.

- An anomalous origin of left circumflex artery arising from the right coronary artery with a subaortic course is an exceedingly rare association of DCRV.

- Preoperative recognition of the pattern of coronary involvement may be clinically significant as the anomalous vessel precariously courses between the dilated right atrium and aortic root where it can get compressed between the two structures.

Contributors All authors have participated sufficiently in the conception of the idea, development of the intellectual content, design, writing and final approval of the manuscript.

Funding The authors have not declared a specific grant for this research from any funding agency in the public, commercial or not-for-profit sectors.

Competing interests None declared.

Patient consent for publication Obtained.

Provenance and peer review Not commissioned; externally peer reviewed. 
Copyright 2019 BMJ Publishing Group. All rights reserved. For permission to reuse any of this content visit

https://www.bmj.com/company/products-services/rights-and-licensing/permissions/

BMJ Case Report Fellows may re-use this article for personal use and teaching without any further permission.

Become a Fellow of BMJ Case Reports today and you can:

- Submit as many cases as you like

- Enjoy fast sympathetic peer review and rapid publication of accepted articles

- Access all the published articles

Re-use any of the published material for personal use and teaching without further permission

\section{Customer Service}

If you have any further queries about your subscription, please contact our customer services team on +44 (0) 2071111105 or via email at support@bmj.com.

Visit casereports.bmj.com for more articles like this and to become a Fellow 